\title{
Stranded Seed Implant
}

National Cancer Institute

\section{Source}

National Cancer Institute. Stranded Seed Implant. NCI Thesaurus. Code C105731.

An implant consisting of multiple radioactive pellets linked together. 